\title{
THREE DIMENSIONAL MATHEMATICAL MODEL OF THE IRON ORE SINTERING PROCES*
}

José Adilson de Castro'

\begin{abstract}
In the integrated steel industries the sintering process plays an important role furnishing raw material to the blast furnace. In this work, a computational simulation of the sinter process is developed that is able to predict the most important phenomena within the sintering bed. The model is based on the multi phase concept with multiple components described by conservation equations of each component coupled with the momentum, chemical reactions and heat transfer. The model validation was carried out comparing the model predictions with averaged industrial data and local temperature measurements within the sinter strand. The model predictions presented good agreement with the averaged values measured on the industrial sinter process.
\end{abstract}

Keywords: Sinter; 3d model; Mathematical model.

1 Ph.D. Professor, UFF- Universidade Federal Fluminense, EEIMVR- Escola de Engenharia Industrial Metalúrgica de Volta Redonda, Volta Redonda, Rio de Janeiro, Brasil-Visiting Professor at GIFT/POSTECH - Pohang, Korea.

* Contribuição técnica ao 44 Seminário de Redução de Minério de Ferro e Matérias-primas, 15o Simpósio Brasileiro de Minério de Ferro e 2o Simpósio Brasileiro de Aglomeração de Minério de Ferro, 15 a 18 de setembro de 2014, Belo Horizonte, MG, Brasil. 


\section{INTRODUCTION}

The sintering process is complex and involves various physical and chemical phenomena such as heat, mass and momentum transfer coupled with chemical reactions [1-5]. These phenomena take place simultaneously increasing considerably the complexity of the process analysis and predictions. The raw materials used in the iron ore sintering process are furnished by several sources, from iron ore(mining sinter feed) to dust recycling within the steelworks and addition of slag agents for blast furnace and selected materials to enhance the sinter product quality, namely reactivity and mechanical strength, which plays important role on the blast furnace performance. In the sintering machine operation, the combustion of the solid fuels(coke breeze or anthracite) begins at the top of the layers, and as it moves, a relative narrow band of ignition zone moves downward through the bed, that can be strongly affected by the quality of the raw materials [6-12]. Several chemical reactions and phase transformations are affected, not only due to the heat front changes, but also due to modifications of local gas composition and initial melting temperatures of the mixture of raw materials. When local temperature and composition of the solids is reached, mostly the phase transformations are driven by heat supply and diffusion that take place within the particles bed with the mechanism of liquid formation playing the major role [10-12]. The materials partially melt down when the local temperature reaches the melting temperature and as it moves, the contact with cold gas promotes the re-solidification and thus, the particle agglomeration forms a continuous porous sinter cake. The final sinter product properties are strongly dependent upon the thermal cycle, initial raw materials chemical composition and thermophysical properties developed during sintering phenomena. In this paper, it is proposed a mathematical model to simulate the phenomena taking place within the sinter machine in the industrial production of sinter to the blast furnace. The focus of this paper is the sinter strand where most of the phenomena which determines the final properties of the sinter product is developed. Previous models addressed the sintering phenomena [1,5,8-12]. At the present days, the reduction of $\mathrm{CO}_{2}$ emissions has become an urgent issue in the steel industry as countermeasure for greenhouse emissions. Therefore, sintering and blast furnace processes offer good opportunities to decrease the $\mathrm{CO}_{2}$ emissions since mall decreasing of the coke breeze consumption and bonding agent used in iron ore sintering process could decisively contribute to decrease the environmental load of the steelmaking industry. Many efforts have been made to make the process cleaner and environmentally acceptable [10,12]. However, the process is complex and only comprehensive models can treat the phenomena and accurately quantifying the impact of new technologies or design feasible operational conditions depending on the available raw materials resources. In the present work, a three dimensional mathematical model of the sinter strand is developed based on the multiphase multicomponent concept and detailed interactions between the gas and solid phases are formulated. The model treats the sinter bed as a mixture of materials and gas and simultaneously momentum, energy and mass transfer occur due to physical and chemical interactions. Thus, the main features of the model can be summarized as follows: a) dynamic interaction of the gas mixture with the solids; b) overall heat transfer of all phases which accounts for convection and radiation phenomena; $c$ ) kinetics of vaporization and condensation of water; d) decomposition of carbonates; e) reduction and oxidation of the iron bearing materials; f) coke combustion and gasification; g) volatile matter evolution; h) shrinkage of the packed bed; h) partial

* Contribuição técnica ao 44 Seminário de Redução de Minério de Ferro e Matérias-primas, 15ㅇ Simpósio Brasileiro de Minério de Ferro e 2o Simpósio Brasileiro de Aglomeração de Minério de Ferro, 15 a 18 de setembro de 2014, Belo Horizonte, MG, Brasil. 
melt and re-solidification of the solids and i) phase changes to form alumina-calciumsilicates.

\section{METHODS}

A procedure to model the sintering process of an industrial strand machine is proposed based on multiphase, multi-component transport equations of momentum, mass and energy for gas, solid and liquid phases taking into account the local phenomena of porous sinter formation, as schematically shown in Fig. 1. The model considers the phases interacting simultaneously and the chemical species of each phase is calculated based on the chemical species conservation equations. The chemical species are individually taken into account by solving the transport equation of each chemical species of the gas and solid phases.

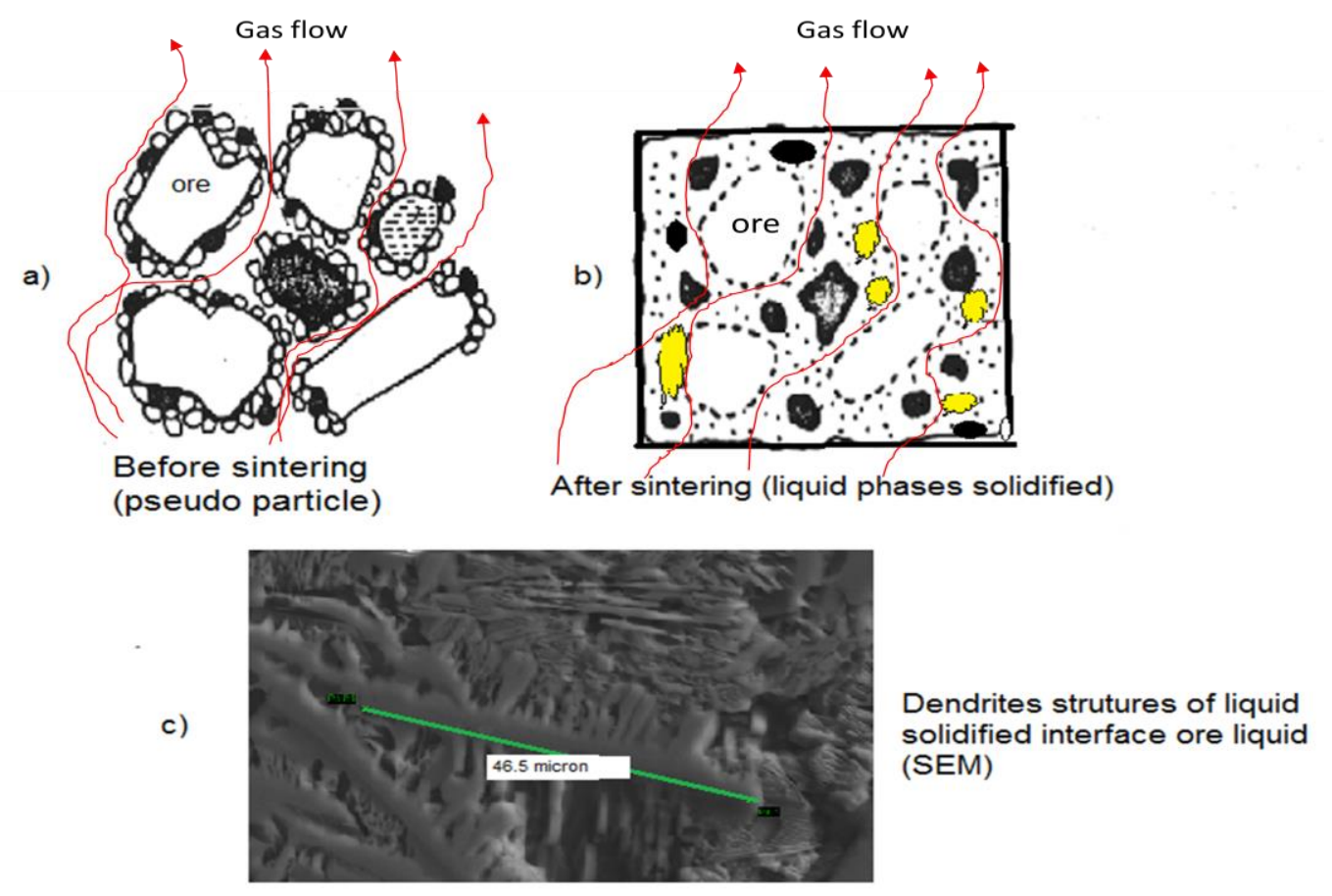

Figure 1. Microstructural aspects and phenomena within the sinter bed.

The solid phase accounts for the mixture of iron ore sinter feed, fine sinter(returned fine sinter), coke breeze(or other solid fuel), scales(fines from steel plant), fluxes and limestone. The liquid phase is composed of melted and formed components in the liquid phase $[1,3,4]$. The re-solidified phase comprises the liquids re-solidified and phases formed during the re-solidification process and strongly depends on the local liquid composition and heat exchange. The final sinter product will be formed by a mixture of these materials and its quality will depend upon the final compositions and volume fractions of each of these materials and their distribution within the mosaic sinter structure. In the present model it is assumed that the liquid phase formed will move together with the remaining solid phase due to the viscosity and considering that the liquid are formed attached on the surface of the unmelted particles, thus, equations for momentum transfer and enthalpy of the solids will account for this mixture of viscous liquid and solid materials. In the present model, the temperaturecomposition dependent thermophysical properties are assumed to obeys the mixture

* Contribuição técnica ao $44^{\circ}$ Seminário de Redução de Minério de Ferro e Matérias-primas, 15오 Simpósio Brasileiro de Minério de Ferro e 2ํ Simpósio Brasileiro de Aglomeração de Minério de Ferro, 15 a 18 de setembro de 2014, Belo Horizonte, MG, Brasil. 
rule to take into account the individual phase properties pondered by their phase volume fractions [5-12]. The equations for momentum, energy and chemical species are convective-diffusive type equations with source and sink accounting for the external or interphase interactions phenomena, taking into account the transient, convective, conductive and source terms[6-12].

Momentum:

$$
\frac{\partial\left(\rho_{i} \varepsilon_{i} u_{i, j}\right)}{\partial t}+\frac{\partial\left(\rho_{i} \varepsilon_{i} u_{i, k} u_{i, j}\right)}{\partial x_{k}}=\frac{\partial}{\partial x_{k}}\left(\mu_{i} \frac{\partial u_{i, j}}{\partial x_{k}}\right)-\frac{\partial P_{i}}{\partial x_{j}}-F_{j}^{i-l}
$$

Continuity:

$$
\frac{\partial\left(\rho_{i} \varepsilon_{i}\right)}{\partial t}+\frac{\partial\left(\rho_{i} \varepsilon_{i} u_{i, k}\right)}{\partial x_{k}}=\sum_{m=1}^{\text {Nreacts }} M_{n} r_{m}
$$

Enthalpy balance:

$$
\frac{\partial\left(\rho_{i} \varepsilon_{i} h_{i}\right)}{\partial t}+\frac{\partial\left(\rho_{i} \varepsilon_{i} u_{i, k} h_{i}\right)}{\partial x_{k}}=\frac{\partial}{\partial x_{k}}\left(\frac{k_{i}}{C_{p_{i}}} \frac{\partial h_{i}}{\partial x_{k}}\right)+E^{i-l}+\sum_{m=1}^{N r e a c t s} \Delta h_{m} r_{m}
$$

The chemical species are individually considered within the phase, for gas, or components of the solid or liquid phases, as presented in Eq. (4).

$$
\frac{\partial\left(\rho_{i} \varepsilon_{i} \phi_{n}\right)}{\partial t}+\frac{\partial\left(\rho_{i} \varepsilon_{i} u_{i, k} \phi_{n}\right)}{\partial x_{k}}=\frac{\partial}{\partial x_{k}}\left(D_{n}^{\text {eff }} \frac{\partial \phi_{n}}{\partial x_{k}}\right)+\sum_{m=1}^{\text {Nreacts }} M_{n} r_{m}
$$

Where indexes $\mathrm{i}$ and $\mathrm{I}$ represent the phases, $\mathrm{j}$ and $\mathrm{k}$ are the indexes for coordinates component direction $n$ is chemical species and $m$ the indicator of the reactions, $M$ is the molecular weight of the species, $P$ is phase pressure, $F$ is component of momentum interactions among the phases and $r$ is the rate of chemical reactions. $\rho, \varepsilon, \mathrm{Cp}, \mathrm{k}$ and $\Delta \mathrm{h}$ are phase density, volume fractions, heat capacity, heat conductivity and heat due to chemical reactions, respectively. The quantity $E^{i-1}$ is the heat transfer among the phases and accounts for convective and radiation heat transfer, since conductive heat transfer is include in Equations (3). The gas -solids momentum interactions are represented by $\mathrm{F}^{\mathrm{i}-\mathrm{I}}$. The model equations are completed with suitable correlations for the thermophysical properties of the phases, rate equations for the source terms and the initial and boundary conditions representing the sintering process. Within the bed the model considers solid combustion, carbonates decomposition, iron ore reduction and re-oxidation, melting and re-solidification, water vaporization and liquid phases formation. The kinetics of these transformations depends on the local temperature and composition. The rate equations for the chemical reactions considered in this model where obtained from literature [1-12]. The model formulation represented by Equations (1)-(4) are completed with the initial and boundary conditions. The computational domain is defined by the region of the sinter strand for the case of the industrial scale process simulation and the equations are solved considering steady state conditions, therefore the first terms on the left of the equations are set to zero and the initial conditions are regard as initial tentative values for the numerical interactions. Regarding to the boundary conditions for the solid phase, the composition, initial and inlet particle diameters, charging particle and volume fractions distributions and moisture content are specified at the charging

* Contribuição técnica ao 44 Seminário de Redução de Minério de Ferro e Matérias-primas, 15오 Simpósio Brasileiro de Minério de Ferro e 2ํ Simpósio Brasileiro de Aglomeração de Minério de Ferro, 15 a 18 de setembro de 2014, Belo Horizonte, MG, Brasil. 
position of the strand. The chemical compositions of the raw materials used in this study as inlet conditions is presented in Table 1. The outlet boundary condition for the solid phase is assumed fully developed flow and no sleep condition is assumed at the sinter strand. The other boundaries such as lateral and bed surface are assumed zero velocities components gradient. For the energy balance equations convective and radiation coefficients are assumed for each of these surfaces(assumed $150 \mathrm{~W} / \mathrm{m} 2 \mathrm{~K}$ and emissivity 0.8 for gas and solid phases). The gas inlet and outlet flow rates are determined by the pressure drop specified for each wind box and it is calculated interactively by considering simultaneously the mass balance and pressure drop of each wind box.

Table 1: Chemical compositions of the raw materials used as input for the model

\begin{tabular}{|c|c|c|c|c|c|c|c|c|c|}
\hline \multicolumn{10}{|c|}{ Iron and flux sources(\%mass) } \\
\hline & $\mathrm{C}$ & CLW & $\mathrm{Fe}_{2} \mathrm{O}_{3}$ & $\mathrm{Fe}$ & $\mathrm{H}_{2} \mathrm{O}$ & $\mathrm{SiO}_{2}$ & $\mathrm{Al}_{2} \mathrm{O}_{3}$ & $\mathrm{MgO}$ & $\mathrm{CaO}$ \\
\hline $\begin{array}{c}\text { Iron ore } \\
\text { sinter feed }\end{array}$ & - & 2.4 & 92.0 & - & - & 3.5 & 1.3 & 0.4 & 0.4 \\
\hline $\begin{array}{l}\text { Returned sinter } \\
\text { (bed formation) }\end{array}$ & - & - & 87.4 & - & 1.3 & 3.2 & 1.2 & 1.3 & 5.6 \\
\hline $\begin{array}{c}\text { Fluxes } \\
\text { (slaging agent) }\end{array}$ & - & - & - & - & 0.8 & 2.5 & 1.4 & $\begin{array}{c}13 \\
\left(\mathrm{MgCO}_{3}\right)\end{array}$ & $\begin{array}{c}82 \\
\left(\mathrm{CaCO}_{3}\right)\end{array}$ \\
\hline \multicolumn{10}{|c|}{ Solid fuel(\% mass) } \\
\hline & $\mathrm{C}$ & VM & $\mathrm{Fe}_{2} \mathrm{O}_{3}$ & $\mathrm{Fe}$ & $\mathrm{H}_{2} \mathrm{O}$ & $\mathrm{SiO}_{2}$ & $\mathrm{Al}_{2} \mathrm{O}_{3}$ & $\mathrm{MgO}$ & $\mathrm{CaO}$ \\
\hline Coke breeze & 86.9 & 1.4 & - & - & 4.3 & 4.1 & 3.0 & 0.1 & 0.2 \\
\hline Scale & 31.9 & 3.1 & 10.8 & 35.5 & 5.8 & 6.6 & 4.1 & 0.4 & 1.7 \\
\hline
\end{tabular}

VM: Volatile mater $-\mathrm{H}_{2} \mathrm{O}$ : Humidity CWL: Calcination weight loss

The gas inlet temperature is specified at the surface of the bed and the outlet temperature are calculate by assuming fully developed flow. As for the chemical species for the gas phase, specified values on the surface of the sinter bed are assumed and similarly the solid phase the outlet values are calculated by using fully developed flowing conditions at the bottom of the bed. The strand velocity and dimensions(width, length and bed height) are given as input data for each machine. The multiphase model is composed of a set of partial differential equations that can only be solved by numerical methods due to their nonlinearities on the boundary conditions and source terms. In this work, the set of differential equations described above is discredited by using the finite volume method [13] and the resulting set of algebraic equations are solved by the iterative procedure using the line by line method combined with the tri-diagonal matrix solver algorithm [13]. In this paper, the numerical grid used to simulate the industrial strand of the sinter machine was discretized based on the Cartesian coordinate system with $15 \times 140 \times 16$ control volumes, assumed suitable for the calculations after continuous grid refinement procedure to assure solutions independence of the control volume size. The momentum transfer between the solid and gas are modeled based on the modified Ergun's equation, which takes into account the local soft-melting behavior of the raw materials with the volume fraction and effective diameters modified by the softmelting data, as follows [10-12]

$$
F_{j}^{g-s}=\left[1.75 \rho_{g}+\frac{150 \mu_{g}}{\left|\vec{U}_{g}-\vec{U}_{s}\right|}\left(\frac{\varepsilon_{s}}{d_{s} \varphi_{s}}\right)\right]\left(\frac{\varepsilon_{s}}{\left(1-\varepsilon_{s}\right)^{3} d_{s} \varphi_{s}}\right)\left|\vec{U}_{g}-\vec{U}_{s}\right|\left(u_{g, j}-u_{s, j}\right)
$$

* Contribuição técnica ao 44 Seminário de Redução de Minério de Ferro e Matérias-primas, 15은 Simpósio Brasileiro de Minério de Ferro e 2 Simpósio Brasileiro de Aglomeração de Minério de Ferro, 15 a 18 de setembro de 2014, Belo Horizonte, MG, Brasil. 
The overall heat transfer coefficient between the gas and the packed bed is given by Equation (6).

$$
E^{g-s}=\frac{6 \varepsilon_{s}}{d_{s} \varphi_{s}} \frac{k_{g}}{\left(d_{s} \varphi_{s}\right)}\left[2+0.39\left(\operatorname{Re}_{g-s}\right)^{1 / 2}\left(\operatorname{Pr}_{g}\right)^{1 / 3}\right]\left(T_{g}-T_{s}\right)
$$

As shown in eq. 6, the gas-solid system inter-phase heat transfer is given by the product of the overall effective heat transfer coefficient, the interfacial area and the average temperature differences of the bed and gas phase. The parameters of the sinter bed $\varepsilon s$ ds and $\varphi s$ are temperature dependent and account for the effective volume fraction, particle diameter and shape factor, respectively, which strongly affect the momentum and energy transfer on the soft-melting zone. The solid diameters and shape factors are given as raw materials properties from the harmonic average of the particle size distributions. In the present model these parameters are calculated by using soft-melting experimental data for the raw materials used [7], as presented by Equations (7)-(9).

$$
\begin{aligned}
& \varepsilon_{i}=1-\left(0.403\left[100 d_{i}\right]^{0.14}\right)\left(1-\operatorname{MAX}\left(0, \operatorname{MIN}\left(1,\left(\frac{T_{s}-T_{i m}}{\Delta T_{m}}\right)\right)\right) \frac{S_{m}}{100}\right) \\
& \varepsilon_{s}=\sum \varepsilon_{i}+\varepsilon_{l}+\varepsilon_{l s} \\
& d_{s}=d_{\text {initial }}+\left(d_{\text {final }}-d_{\text {initial }}\right)\left(\frac{\varepsilon_{l}+\varepsilon_{l s}}{\varepsilon_{s}}\right)^{3}
\end{aligned}
$$

Where i stands for iron ore sinter feed, retuned sinter, solid fuels, fluxes and scales on the sintering mixture charged on the sinter bed, I and Is are the liquid and solid bridges volume fractions formed during sintering phenomena. The average size of the sintering structure are given by Equation (9) with the parameters dinitial and dfinal representing the average particle size of the quasi particles charged in the bed and the particle size for complete sintering product.

\section{RESULTS AND DISCUSSIONS}

In this study temperature measurement within the sinter bed were carried out and the averaged values of the temperatures where used to compared with the numerical predictions with the correspondent input average data of strand velocity and raw materials mix. Fig. 2 shows the gas vectors velocity and temperature predictions for the middle vertical plane of the sinter strand. As can be observed, the gas velocity gradually increases as the sinter strand moves. This results is explained by the effect on the gas flow of bed permeability evolution and density changes of the gas phase due to changes in the gas temperature, pressure and composition (this model uses the ideal gas relation to account for this effects on the density). Figure 3 presents the comparison of temperature predictions by the model and measured data obtained in the industrial sintering machine for the actual operation conditions. The calculated results were compared with the averaged measured data obtained by thermocouples

* Contribuição técnica ao $44^{\circ}$ Seminário de Redução de Minério de Ferro e Matérias-primas, 15오 Simpósio Brasileiro de Minério de Ferro e 2ํ Simpósio Brasileiro de Aglomeração de Minério de Ferro, 15 a 18 de setembro de 2014, Belo Horizonte, MG, Brasil. 
inserted within the sinter bed on fixed positions of $75 \mathrm{~mm}, 355 \mathrm{~mm}$ and $725 \mathrm{~mm}$ within the bed and the temperatures were recorded on intervals of $10 \mathrm{~m}$ along the strand. As can be observed, the measured and predicted values are in excellent agreement, considering that the temperature are strongly effect by all the phenomena simultaneously taking place in the sinter bed such as interphase heat transfer, phase changes, momentum transfer and chemical reactions. These results indicated that the model is enough accurate to predict the industrial process of iron ore sintering under several operational conditions. Table 2 presents global parameters predicted and calculated with the model. As average the model parameters are in good agreement with the sinter machine operation.

Table 2. Global parameters predicted by the mathematical model

\begin{tabular}{|l|c|c|c|c|c|c|c|c|}
\hline & $\begin{array}{c}\text { Production } \\
(\mathrm{t} / \mathrm{h})\end{array}$ & $\begin{array}{c}\text { Productivity } \\
\left(\mathrm{t} / \mathrm{m}^{2} / \text { day }\right)\end{array}$ & $\begin{array}{c}\text { Gas flow } \\
\left(\mathrm{Nm}^{3} / \mathrm{min}\right)\end{array}$ & $\begin{array}{c}\text { Fuel } \\
(\mathrm{kg} / \mathrm{t})\end{array}$ & $\begin{array}{c}\text { Sinter } \\
\text { feed } \\
(\mathrm{kg} / \mathrm{t})\end{array}$ & $\begin{array}{c}\text { Return } \\
\text { sinter } \\
(\mathrm{kg} / \mathrm{t})\end{array}$ & $\begin{array}{c}\text { Fluxes } \\
(\mathrm{kg} / \mathrm{t})\end{array}$ & $\begin{array}{c}\text { Suction } \\
\text { depression } \\
(\mathrm{kPa})\end{array}$ \\
\hline Process & 822.5 & 40.6 & 14565.5 & 45.1 & 573.3 & 323.9 & 133.1 & 14.1 \\
\hline Model & 827.5 & 41.2 & 14451.3 & 45.8 & 573.8 & 323.0 & 133.8 & 13.8 \\
\hline $\begin{array}{l}\text { Error } \\
(\%)\end{array}$ & 0.4 & 0.2 & 0.8 & 1.8 & 0.1 & 0.9 & 0.5 & 2.1 \\
\hline
\end{tabular}

Other parameters

\begin{tabular}{|c|c|c|c|c|c|}
\hline $\begin{array}{l}\text { Initial pseudo } \\
\text { particle } \\
\text { diameter (mm) } \\
\text { (input data) } \\
d_{\text {initial in Eq.(9) }}\end{array}$ & $\begin{array}{c}\text { Final particle } \\
\text { diameter }(\mathrm{mm}) \\
\text { (calculated) } \\
d_{\text {final }} \text { in Eq. }(9)\end{array}$ & $\begin{array}{l}\text { Coke breeze } \\
\text { average } \\
\text { particle } \\
\text { diameter } \\
\text { (mm) } \\
\text { (input data) }\end{array}$ & $\begin{array}{c}\text { Iron ore } \\
\text { particle } \\
\text { diameter } \\
\text { (mm) } \\
\text { (input data) }\end{array}$ & $\begin{array}{c}\text { Limestone } \\
\text { particle } \\
\text { diameter(mm) } \\
\text { (input data) }\end{array}$ & $\begin{array}{c}\text { Liquid } \\
\text { solidified (\%) } \\
\text { (calculated) }\end{array}$ \\
\hline 7.5 & 40 & 3.2 & 4.3 & 1.5 & 65 \\
\hline \multicolumn{2}{|c|}{$\begin{array}{l}\text { Initial temperature }-\left(T_{\text {im, }}\right) \\
\text { in Eq. }(7)\left({ }^{\circ} \mathrm{C}\right)\end{array}$} & \multicolumn{2}{|c|}{$\begin{array}{l}\text { Melting interval }\left(\Delta T_{m}\right) \\
\text { in Eq. }(7)\left({ }^{\circ} \mathrm{C}\right)\end{array}$} & \multicolumn{2}{|c|}{$\begin{array}{c}\text { Shrinkage }\left(S_{m}\right) \\
(\%)\end{array}$ in Eq. (7) } \\
\hline \multicolumn{2}{|c|}{1055} & \multicolumn{2}{|c|}{215} & \multicolumn{2}{|c|}{35} \\
\hline
\end{tabular}

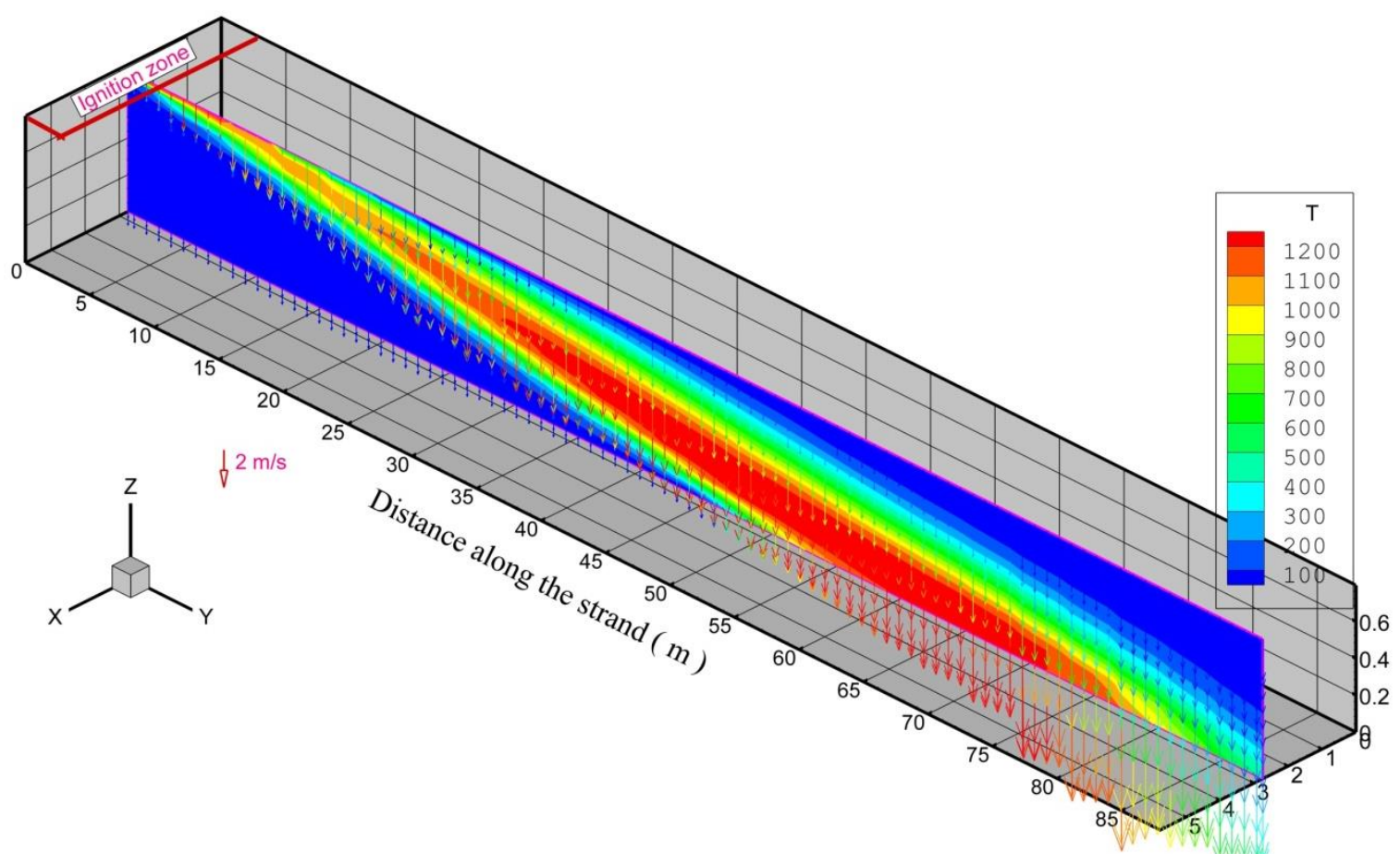

Figure 2. Combustion front and gas flow vector for the middle section of the sinter strand.

* Contribuição técnica ao $44^{\circ}$ Seminário de Redução de Minério de Ferro e Matérias-primas, 15오 Simpósio Brasileiro de Minério de Ferro e 2ํ Simpósio Brasileiro de Aglomeração de Minério de Ferro, 15 a 18 de setembro de 2014, Belo Horizonte, MG, Brasil. 


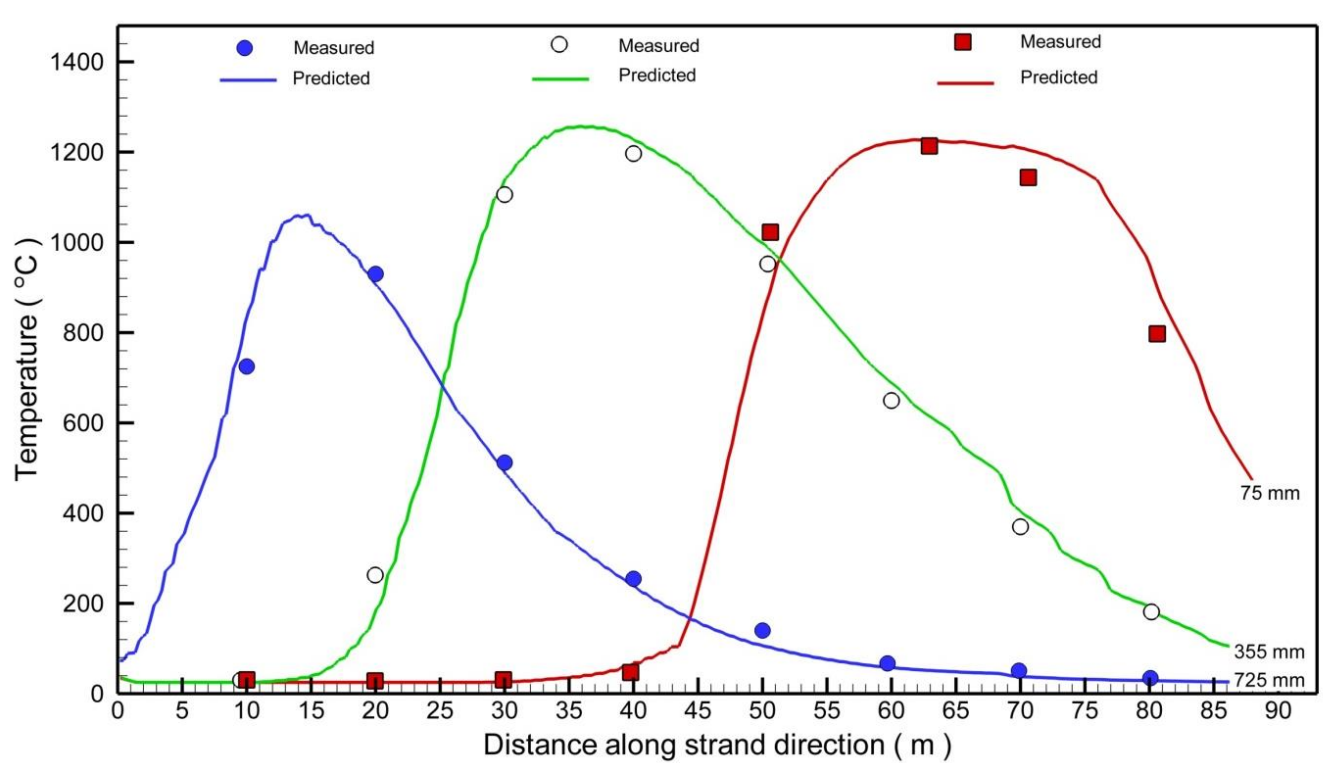

Figure 3. Model verification with temperatures measured inside the sinter bed.

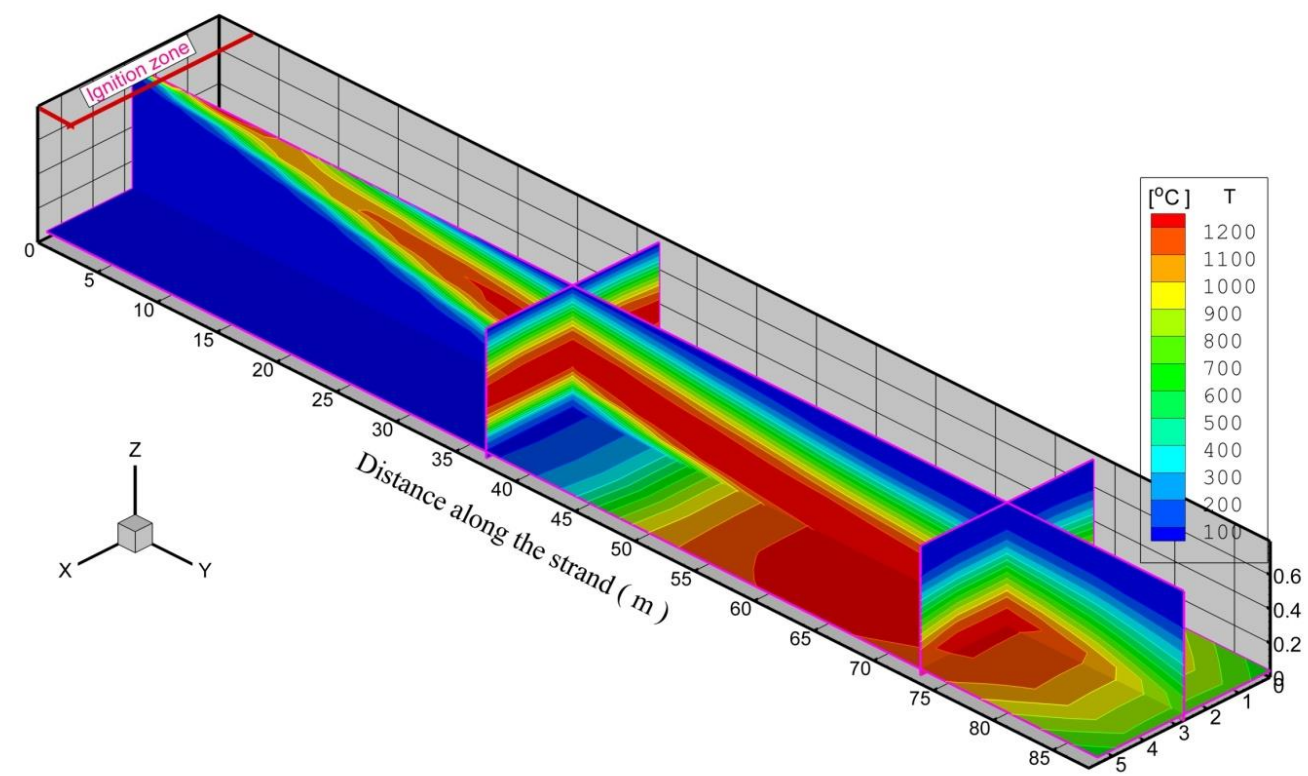

Figure 4. Tridimensional features of the temperature distribution within the sinter bed.

Figure 4 shows tridimensional slices of the sinter bed indicating the temperature distributions. As observed, the tridimensional nature of the process is evidenced. This model allows the treatment of these asymmetric conditions for treatment of the non symmetry features due to bed charging and preferential gas flow. As can be observed, at the burnt out region the heat solicitation of the bed is important and where the boundary effects are pronounced.

\section{CONCLUDING REMARKS}

This paper presents a mathematical model for predicting the phenomena within the sinter bed. The model is a multiphase 3D mathematical model able to simulate the process phenomena of the sinter bed of an industrial operation. The model is based on transport equations of momentum, energy and chemical species coupled with

* Contribuição técnica ao $44^{\circ}$ Seminário de Redução de Minério de Ferro e Matérias-primas, 15ํ Simpósio Brasileiro de Minério de Ferro e $2^{\circ}$ Simpósio Brasileiro de Aglomeração de Minério de Ferro, 15 a 18 de setembro de 2014, Belo Horizonte, MG, Brasil. 
chemical reaction rates, which takes into account the phase flows, heat exchange and mass transfer considering the chemical reactions and phase transformations. Model verification was carried out by comparison of sinter bed temperature measurements obtained by inserting thermocouples into the sinter bed of the industrial sinter machine. It was demonstrated the 3D behavior of the sinter front and inner temperature distributions. The model was able to simulate the actual sinter operation conditions and could be an useful tool to design optimum operation conditions of the industrial sintering machine.

\section{Acknowledgments}

The author thanks to FINEP, CAPES, CNPq and FAPERJ for the financial support.

\section{REFERÊNCIAS}

1 Yamaoka, $\mathrm{H}$. and Kawaguchi, T. Development of a 3-D sinter process mathematical simulation model . ISIJ International. 2005;45(4):522-531.

2 Nath, N. K. Silva, A.J and Chakraborti, N. Dynamic process modeling of iron ore sintering. Steel Research. 1997; 68(7):285-292.

3 Oyama, N. Iwami, Y. Yamamoto, T. Machida, S. Yguchi, T. Sato, H. Takeda, K. Watanabe, Y. and Shimizu, M. Development of secondary-fuel injection technology for energy reduction in the iron ore sintering process. ISIJ International. 2011; 51(6):913921.

4 Hayashi, N. Komarov, S. V. and Kasai, E. Heat transfer analysis of mosaic embedding iron ore sinter (MEBIOS) process. ISIJ International. 2009; 49(5):681-686.

5 Guilherme, V.S. Castro, J.A. Utilização de gás de coqueria na sinterização de minério de ferro. REM: Revista Escola de Minas. 2012; 65 (3): 357-362.

6 Castro, .J. A. Sasaki, Y. Yagi, J. Three dimensional mathematical model of the iron ore sintering process based on multiphase theory. Materials Research. 2012;15(6):848-858.

7 Castro, J.A. França, A.B. Guilherme, V. S. Sasaki, Y. Estudo numérico da influência de propriedades de amolecimento e fusão na cinética de formação de $\left(\mathrm{CaFe}_{2} \mathrm{O}_{4}\right.$ $\mathrm{Ca}_{2} \mathrm{Fe}_{2} \mathrm{O}_{5}$ ) na sinterização de minério de ferro, TMM-Tecnologia em Metalurgia, Materiais e Mineração. 2013;10(1):16-27.

8 Castro, J.A. Guilherme, V.S. França, A.B. Sasaki, Y. Iron ore sintering process based on alternative gaseous fuels from steelworks. Advanced Materials Research. 2012;535537(1):554-560.

9 Castro, J.A. Nath, N. França, A.B. Guilherme, V.S. Sasaki, Y. Analysis by multiphase multicomponent model of iron ore sintering based on alternative steelworks gaseous fuels, Ironmaking Steelmaking. 2012; 39(8): 605-613.

10 Castro JA, Pereira JL. Guilherme VS. Rocha E.P. and França AB. Model predictions of PCDD and PCDF emissions on the iron ore sintering process based on alternative gaseous fuels, J Mater Res Technol.2013;2(4):323-331.

11 Castro JA. Model predictions for new iron ore sintering process technology based on biomass and gaseous fuels. Advanced Materials Research. 2014;918(1):136144/10.4028/www.scientific.net/AMR.918.136

12 Castro JA, Ferreira AF, Campos FIL. Modeling a compact sintering process based on biomass fuels. Advanced Materials Research.2014;902(1):33-40/

10.4028/www.scientific.net/AMR.902.33

13 Patankar SV. Numerical heat transfer and fluid flow. Hemisphere, Washington, D. C., 1980

\footnotetext{
* Contribuição técnica ao $44^{\circ}$ Seminário de Redução de Minério de Ferro e Matérias-primas, 15ํ Simpósio Brasileiro de Minério de Ferro e $2^{\circ}$ Simpósio Brasileiro de Aglomeração de Minério de Ferro, 15 a 18 de setembro de 2014, Belo Horizonte, MG, Brasil.
} 